\title{
往復正方形断面流路内乱流における 傾斜リブと急激曲がりによる二次流れの干渉*
}

\author{
齋藤 博 史*1, 村田 章*1, 望月貞 成*2
}

\section{Interference Between Secondary Flows Caused by Angled-Ribs and Sharp Turn in Turbulent Flow of Square Two-Pass Channel}

\author{
Hiroshi SAITO*3, Akira MURATA and Sadanari MOCHIZUKI
}

${ }^{* 3}$ Department of Mechanical Systems Engineering, Graduate School of Engineering,
Tokyo University of Agriculture and Technology, 2-24-16 Nakacho, Koganei-shi, Tokyo, 184-8588 Japan

This study experimentally deals with turbulent flow inside transverse- ${ }^{-}$or angled-rib-roughened square two-pass channel in stationary condition. Details of the two-dimensional flow field were quantitatively measured by using a particle image velocimetry to which was applied Frame-staddling method with high-resolution CCD camera. Angled-ribs generated secondary flow along the rib, flow separation, and reattachment similar to the transverse-rib case. A secondary flow of turning flow caused by a centrifugal force in a sharp turn was stronger than that caused by the angled ribs. Furthermore, the interference between the secondary flow by the sharp turn and the angled ribs was observed and high turbulence intensity between the ribs and after the sharp turn as a result of highly fluctuating unsteady fluid motion was clearly captured.

Key Words: Turbulent Flow, Gas Turbine, Particle Tracking Velocimetry, Flow Visualization, Secondary Flow, Rib-Roughened Two-Pass Channel

\section{1. 緒 言}

航空用ガスタービンエンジンは高温の燃焼ガスを用 いるので，タービン翼は非常に過酷な温度環境下にお かれる. 而熱性の向上には材料・冷却両技術が重要と なり，タービン翼冷却は材料強度を維持する上で必須 である.タービン翼冷却には，図 1 に示すように翼表 面の孔から冷却空気を放出するフィルム冷却と翼内部 の往復冷却流路を用いた強制対流内部冷却が行われ， 冷却流路内部には熱的負荷の大きい翼面側にリブ（乱 流促進突起）が設けられている.このリブ付き往復冷 却流路内ではリブによる流れの剥離, 再付着, 二次流 れ，また，直線流路が急激に 180 度折り返す曲がり部 内では，遠心力に起因する二次流れと角部・隅部での 流れの剥離が生じ，さらには曲がり部とリブによって 誘起された流れの干渉により，非常に複雑な流れとな っている.この冷却流路内の熱伝達特性を理解するう えで流動状況を正確に把握することは重要である.

熱伝達特性については，これまでに内部泠却流路を 模擬した 180 度急激曲がり部を持つ, 平滑・リブ付き

\footnotetext{
* 原稿受付 2007 年 6 月 11 日.

*1 正員, 東京農工大学大学院工学府(恶 184-8588 小金井市中 町 2-24-16)

*2 正員, フェロー, 東京農工大学大学院工学府.

E-mail : saito@mmlab.mech.tuat.ac.jp
}

往復矩形流路内の静止・回転場における熱電対を用い た多点壁温計測による詳細な局所熱伝達率計測 ${ }^{(1-4)} や$, Large Eddy Simulation(LES)による流れ場および温度場 の数值解析 ${ }^{(5-6)}$ が行われ, 直線部では, リブによる流 れの剥離・再付着によってリブ間の熱伝達率は平滑流 路に比べ大幅に上昇し, 曲がり部およびその直後では, リブ取り付け角度・配置の違いによって二次流れの様 子が変化し，各壁面の熱伝達率分布に差が生じること が説明されている. 速度場については Laser Doppler Velocimetry $^{(7-8)}$ や, Particle Image Velocimetry (PIV) ${ }^{(9-11)}$ に よる計測が行われているものの，リブ付き往復流路内 の曲がりや，リブにより生じる二次流れに関する詳細

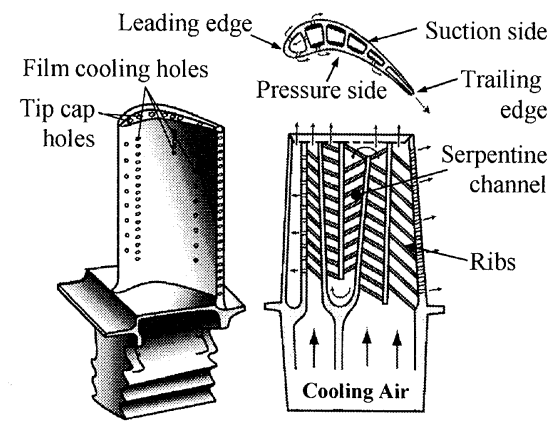

Fig. 1 Schematic of cooling technique for gas turbine blade. 
な速度場計測の例は少ない. 著者らは, 前報(12)におい て 180 度急激曲がり部を有する, 平滑および 90 度リブ 付き往復流路内の Particle Tracking Velocimetry (PTV)に よる二次元速度場計測を行い, リブによる流れの剥 離・再付着, リブ間の乱れ強度の上昇や曲がり部内の 二次流れといった詳細な速度場計測結果を示している.

そこで本研究は, 傾斜 60 度リブ付き正方形断面往復 流路内の二次元 PTV による乱流速度場計測を行い，傾 斜リブにより生じる（90 度リブよりも）強い二次流れ と, 180 度急激曲がり部で流体に働く遠心力の作用によ る二次流れとの干渉によって生じる曲がり部内の流れ への影響を詳細に調べた。

\section{2. 実験装置およひ実験方法}

図 2 に 60 度リブ付き往復流路概略を示す. 作動流体 の水は, 静定室, 絞り部および平滑管助走区間を経て,

First pass, 180 度急激曲がり部, Second pass を流れた後 に出口部より排出される. 管路断面は正方形（一辺長 さ $D[\mathrm{~m}](=80 \mathrm{~mm}))$ で, リブ (正方形断面一辺長さ $0.1 D)$ はピッチ $D$ で流路軸に対して $\theta=90$ 度または 60 度に傾 けて, 流路長さ $11 D$ を有する First pass およびSecond pass の対向二壁面 (Side wall) に対向面で同位置 (in-line)

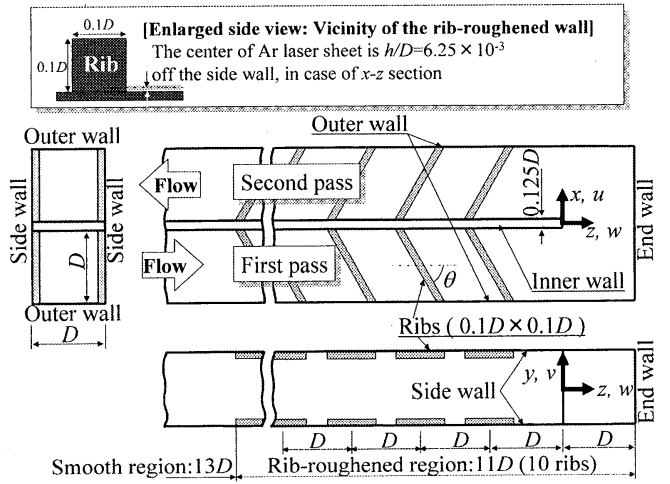

Fig. 2 Schematic of a rib-roughened two-pass channel $(\theta=60$ deg. $)$.

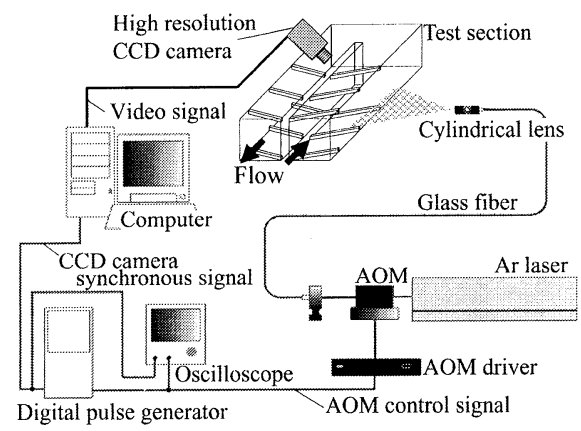

Fig. 3 Schematic of measurement system.
に各々 10 個（合計 40 個）(End wall からの距離 $2 D$ の位 置まで）取り付けられている. 60 度リブ付き往復流路 の場合, リブ配置は曲がり部において流体に生じる遠 心力の作用による二次流れと，傾斜リブによって誘起 される二次流れの向きが，First pass においては反対と なり, Second passにおいては一致するパターンとした

(図 2 参照)。このパターンは，過去の LES による数 值解析 ${ }^{(5)}$ で最大の熱伝達を示すリブパターンと報告さ れている. 実験方法は, 前報 ${ }^{(12)}$ と同じである. Inner wall 先端中央 (Inner wall 厚さ $(=0.125 D)$ 分は $x / D$ から除く) を座標原点として，流路幅方向，リブ面垂直方向，直 線部流路軸力向をそれぞれ $x, y, z$ とし, 各速度成分を $u, v, w$ とした. 光源は厚さ $1 \mathrm{~mm}$ の Arレーザーシート 光 (SPECTRA PHYSICS 社 Model 2017, 使用出力 2W) を用い, $y-z$ 断面, $x-y$ 断面, 流路中央 $x-z$ 断面および Side wall 壁面近傍 $x-z$ 断面（レーザーシート光の中心が壁面 からの距離 $h / D=6.25 \times 10^{-3}$ : 以降, 壁面近傍と呼子”) の計 測を行った。撮影には高解像度 CCD カメラ

(Adimec-1000m，1,000×1,000pixel ${ }^{2}$, 40fps) を用い，撮 影領域は $D \times D$ または， $2 D \times 2 D$ に設定した. レイノ ルズ数は $R e=10,000 \quad\left(R e=U_{m} D / v\right.$, 平均流速 $U_{m}[\mathrm{~m} / \mathrm{s}]$, 動粘性係数 $v\left[\mathrm{~m}^{2} / \mathrm{s}\right] ）$ とした. 流れの可視化手法は粒 子賏濁法を用い，トレーサ粒子に直径約 $50 \mu \mathrm{m}$ のイオ ン交換樹脂（比重 1.01）を使用した.

図 3 にPTV 計測システム概略を示す。レーザライト シート光で照明し, CCD カメラによって得られた粒子 画像より，2 時刻間の粒子追跡(PTV) ${ }^{(13)}$ による二次元 速度場計測を行った. PTV 計測システムは, CCD カメ ラのフレームレートに依存しない，連続 2 画像間の時 間間隔設定 ${ }^{(14)}$ を可能とするため, フレームストラドリ ング法を用い，レーザ光は CCD カメラと同期させて, 音響光学素子 (Acousto-Opptic Modulator : AOM, EOS 社N3508-3）でシャッタリングを行い，遅延時間（連 続 2 パルス光の時間間隔) および露光時間を独立に調

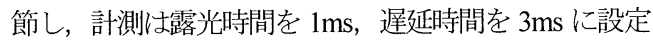

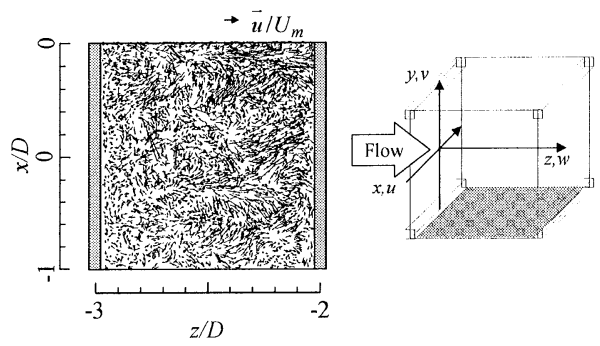

Fig. 4 Instantaneous velocity vectors of $x-z$ section in the vicinity of the rib-roughened wall for $90 \mathrm{deg}$ ribs case $\left(h / D=6.25 \times 10^{-3}\right.$, off the side wall, $R e=10,000$ ). 
し行った.

図 4 に 90 度リブ付き管の壁面近傍 $x-z$ 断面の瞬時速 度ベクトルの例を示す. 瞬時速度べクトルは 1 時刻に $2,000 \sim 4,000$ 個が算出された. 誤ベクトルの発生頻度は 0.1\%以下であったので，誤ベクトル除去は行っていな い. 実験結果は，20,000 フレームの画像から算出され た 10,000 時刻での瞬時ベクトルデータを用いて，平均 速度ベクトル $\vec{U}$, 乱れ強度 $u_{m s}, v_{m s}, w_{m s}$ およびレイノ ルズ応力を算出した. また，平均速度ベクトルは $U_{m}$ で, 乱れ強度は Blasius の式より算出した摩擦速度 $u *$ $[\mathrm{m} / \mathrm{s}]$ （レイノルズ応力は $u_{*}^{2}$ ) を用いて規格化した. 計測の不確かさ解析 (15)において主流速度に対する
不確かさは最大約 4 4\%（95\%包括度）, 乱孔強度に対す る不確かさは最大約 $\pm 5 \%$ （95\%包括度）となった。

\section{3. 結果および考察}

図 5 に 90 度および 60 度リブ付き往復流路の First pass 側, リブ取り付け開始位置からの距離 $7 D$ (End wall から距離 $3 D)$ の曲がり部の影響を受けていない区間の, Side wall 壁面近傍 $x-z$ 断面および流路幅方向中央 $y-z$ 断 面 $(x / D=-0.5)$ の平均速度ベクトル $, u_{m s}, v_{m s}, w_{m s}$ およ びレイノルズ応力 $-\overline{v^{\prime} w^{\prime}}$ ( $y-z$ 断面) の結果を示す. ただし， 90 度リブと 60 度リブ各々のスケールは異なる。 図 5(a)90 度リブの壁面近傍 $x-z$ 断面の結果から, リブ間

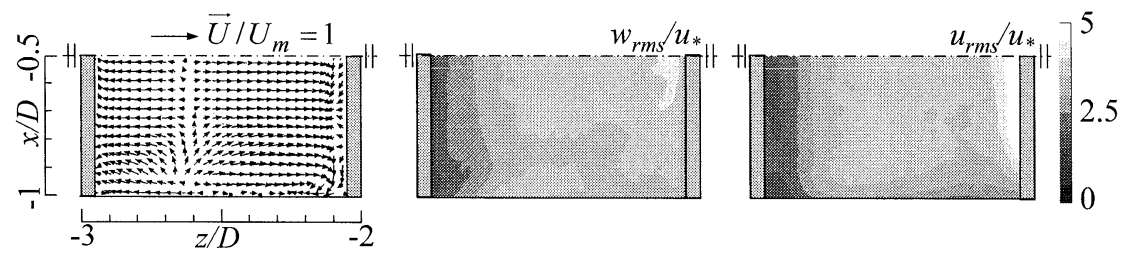

(a) $x-z$ section in the vicinity of the rib-roughened wall for $90 \mathrm{deg}$. ribs case $\left(h / D=6.25 \times 10^{-3}\right.$ off the side wall $)$

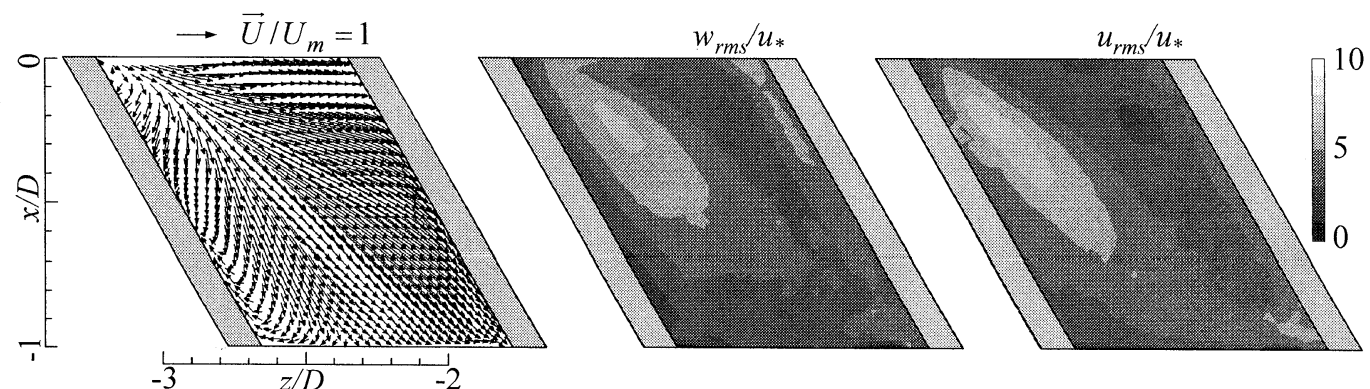

(b) $x-z$ section in the vicinity of the rib-roughened wall for $60 \mathrm{deg}$. ribs case $\left(h / D=6.25 \times 10^{-3}\right.$ off the side wall).
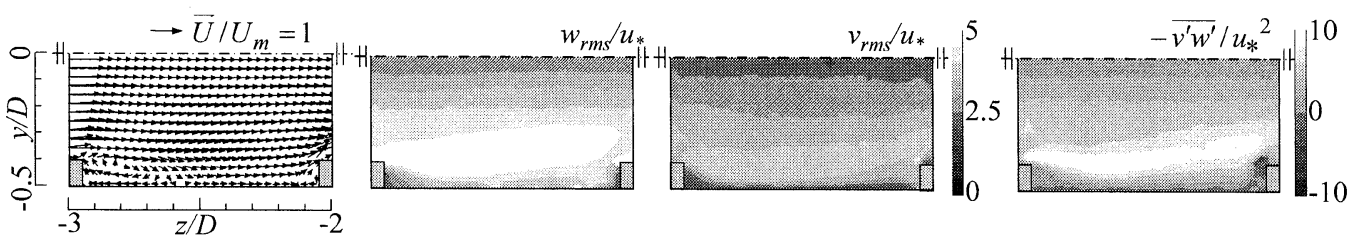

(c) $y-z$ section at the center of the channel width for $90 \mathrm{deg}$. ribs case $(x / D=-0.5)$.

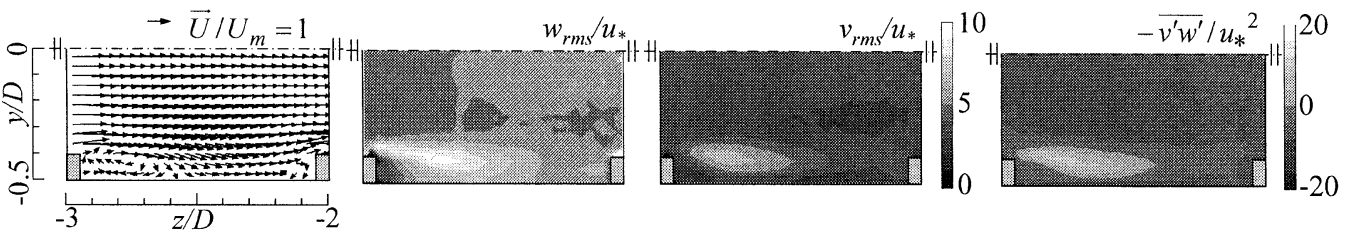

(d) $y$-z cross-section plane at the center of the channel width for $60 \mathrm{deg}$. ribs case $(x / D=-0.5)$.

Fig. 5 Time-averaged velocity vectors, turbulence intensities, and Reynolds stress at the fully developed region in the first pass ( $R e=10,000,7 D$ downstream from the entrance of rib-roughened section). 


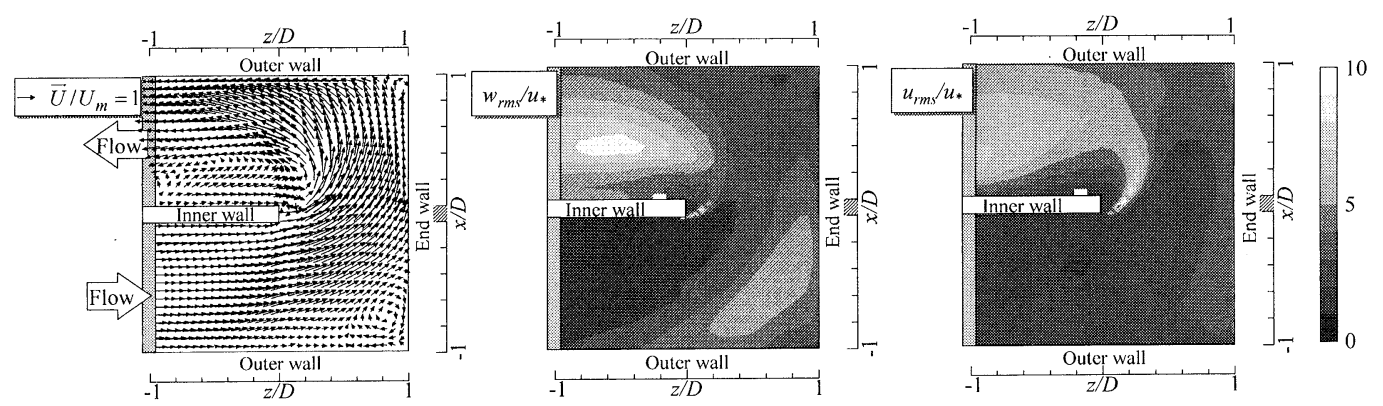

(a) $x-z$ section at the center of the channel height for $90 \mathrm{deg}$. ribs case $(y / D=0)$.

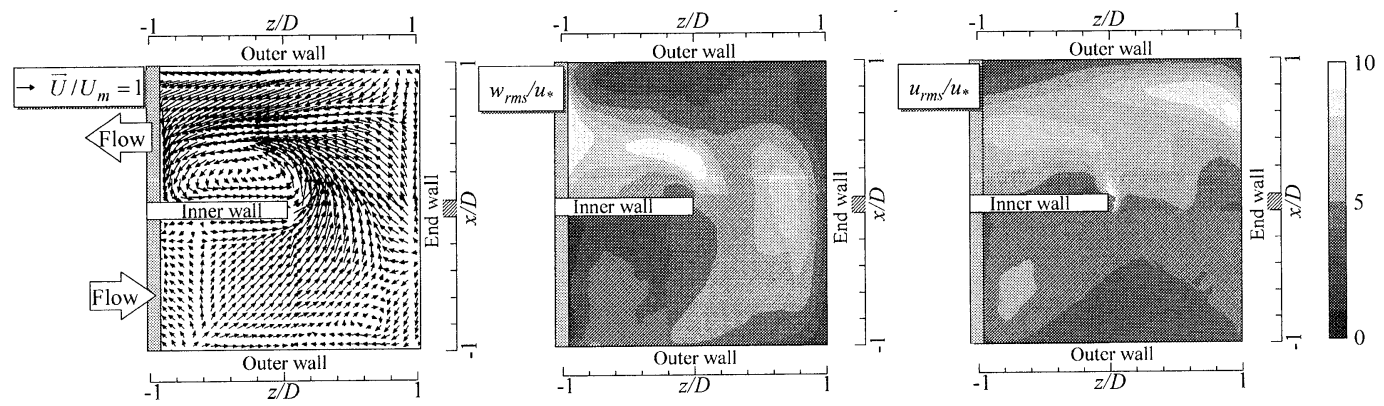

(b) $x-z$ section in the vicinity of the rib-roughened wall for $90 \mathrm{deg}$. ribs case $\left(h / D=6.25 \times 10^{-3}\right.$ off the side wall).
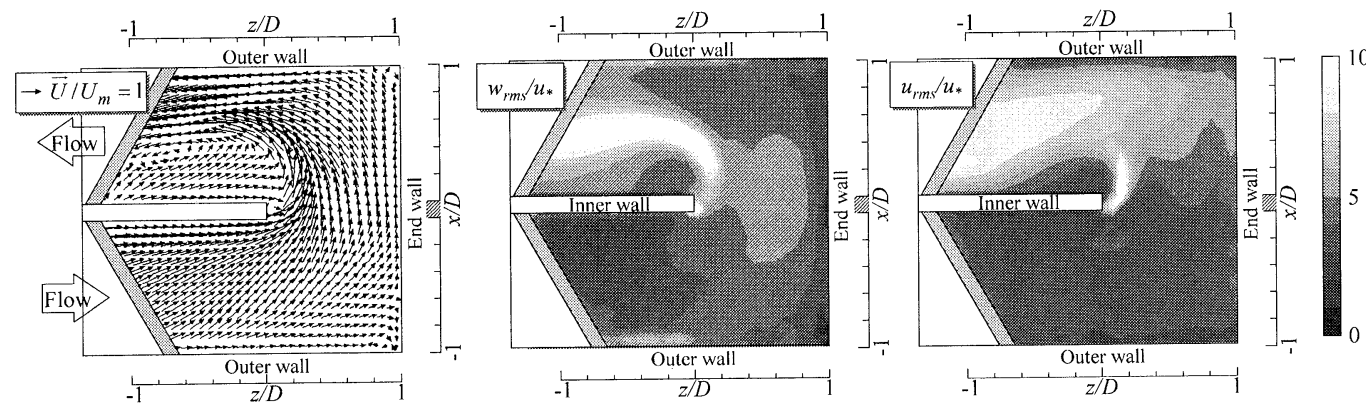

(c) $x-z$ section at the center of the channel height for $60 \mathrm{deg}$. ribs case $(y / D=0)$.
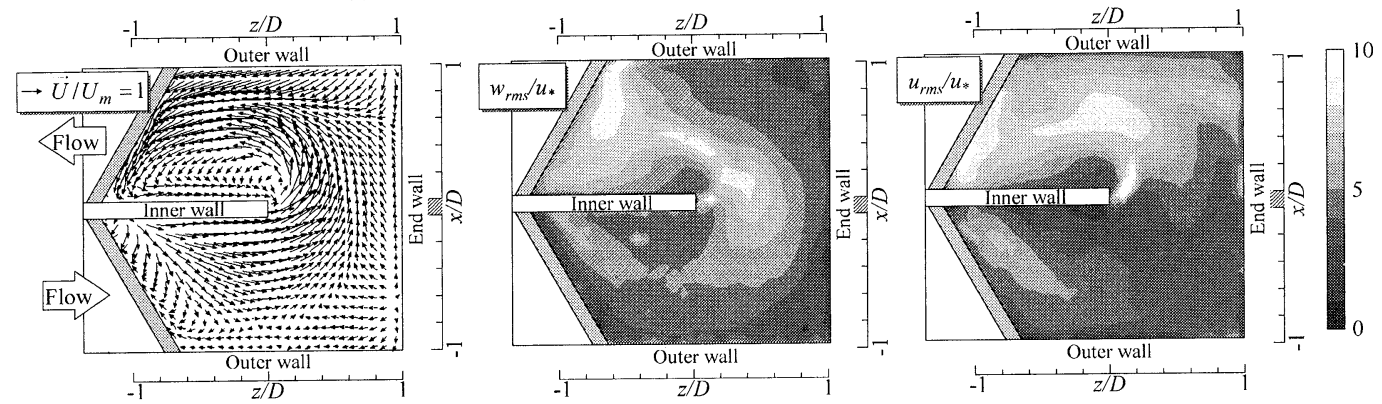

(d) $x$-z section in the vicinity of the rib-roughened wall for $60 \mathrm{deg}$. ribs case $\left(h / D=6.25 \times 10^{-3}\right.$ off the side wall).

Fig. 6 Time-averaged velocity vectors and turbulence intensities at the turning region $(R e=10,000)$.

の流れは，再付着点が $z / D=-2.6$ の位置に確認され，剥 離域となる $z / D<-2.6$ では上流側リブへと向から逆流が 生じている. $u_{m s}, w_{m s}$ は逆流域で低く, $u_{m s}$ の下流側リ ブ直前部の上昇は，リブ上流側側面に当たった流れに
よって誘起された非定常な流路幅方向の流れのためで ある. 図 5(b)60 度リブの場合, 傾斜リブに沿う速い流 れが生じ, $u_{m s}, w_{m s}$ は90度リブよりも全域で高い，図 5(c)90 度リブの流路幅方向中央 $y$ - $z$ 断面でも，図 5(a) と 
同様にリブ間の再付着点，およびリブ直後の再循環領 域が確認される. $v_{r m s}, w_{m s},-\overline{v^{\prime} w^{\prime}}$ はリブ高さと同じ位 置のリブ間で高い：図 5(d)60 度リブの場合, 90 度リブの 場合と同様にリブ後方の再付着点と再循環領域が形成され る. $v_{m s}, w_{m s}$ および- $\overline{v^{\prime} w^{\prime}}$ は，リブ間中央より上流側に 90 度リブに比べて高い極大值をとる. 直線部において, 90 度リブ (図5(a), (c)) では二次元的な流動構造であるものが, 60 度リブ (図 5(b), (d)) では二次元的な流動構造となる.

図 6 に 180 度急激曲がり部を含む $x-z$ 断面幅方向中

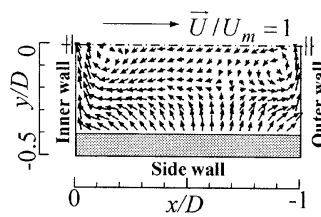

(a) $90 \mathrm{deg}$. ribs case

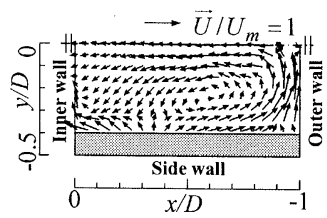

(b) 60deg. ribs case
Fig. 7 Time-averaged velocity vectors in the plane parallel to the ribs at the fully developed region in the first pass $(R e=10,000,8 D$ downstream from the entrance of rib-roughened section).

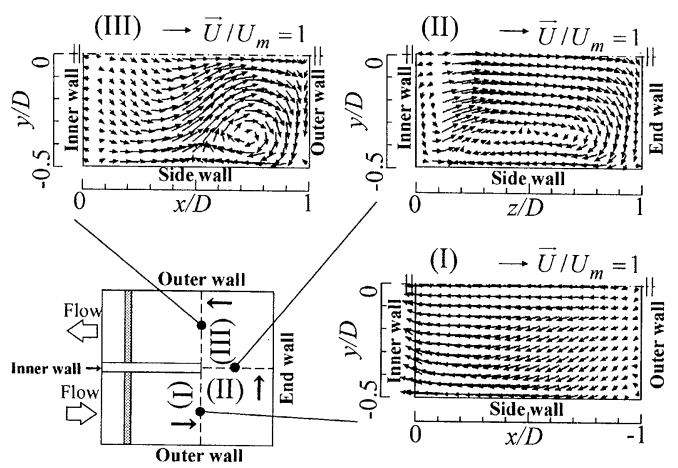

(a) 90deg. ribs case

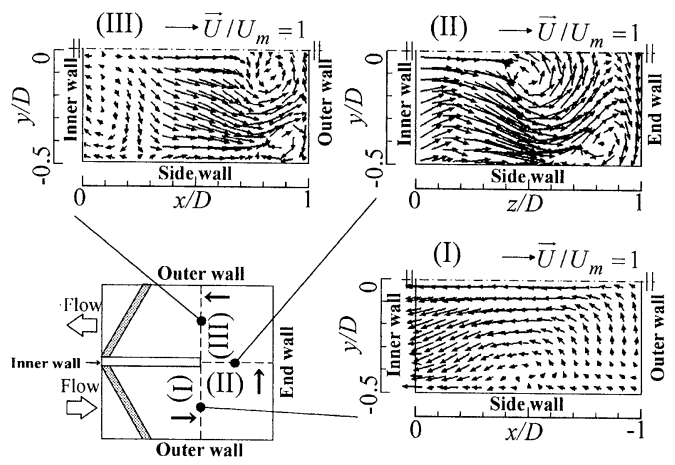

(b) 60deg. ribs case

Fig. 8 Time-averaged velocity vectors in the plane normal to the main flow direction at the turning region $(R e=10,000)$.
央 $(y / D=0)$ および壁面近傍の時間平均速度ベクトル, $u_{r m s}, w_{m s}$ を示す. 90 度リブの場合, $y / D=0$ (図 6(a)) で はFirst pass 側 $z / D=-0.2$ 付近から主流は徐々に Inner wall 側に偏り，Second pass 側では主流に作用する遠心力に よって Outer wall 側に偏る. その結果, Second pass 第 1 番目のリブまでの Inner wall 寄りの領域および End wall 側の角部・隅部に，再循環領域が形成される. $u_{r m s}, w_{m s}$ は Second pass で極大值が確認できる. 図6(b)の 壁面近 傍では，First pass 最終リブ下流側に，リブによる流れ の剥離と再付着が確認され，曲がり部内の流体に働く 遠心力によって生じる二次流れの影響で, 壁面近傍で は Inner wall に向から流れが生じている.また Second pass 第 1 番目のリブに流れは当たり, Inner wall に向か う流れとなり, Inner wall 寄りに再循環領域が形成され る. $u_{m s s}, w_{r m s}$ は, 曲がり部の影響を受けていない領域 (図 5 参照) よりも曲がり部直後から高く, 曲がり部 内および Second pass 側の局所的な $u_{r m s}, w_{m s}$ の上昇は, Second pass 側の Inner wall 寄りの再循環領域と主流との 間のせん断力による乱流生成によって生じたと考えら れる. 60 度リブの場合, $y / D=0$ (図 6(c)) では平均速 度ベクトルは, 90 度リブの場合と同様の傾向を示す. $w_{r m s}$ は90 度リブより Second pass 側で高く, Inner wall 先端部から下流側に連続する高い領域が存在する. 図 6(d)の壁面近傍では First pass 最終リブ下流側において, Inner wall から Outer wall に向かうリブに沿う流れが生 じ，その後向きを変える. $u_{r m s}, w_{r m s}$ は, First pass 最終リ ブ下流の再付着点, および Second pass 側の再循環領域 と主流の境界で，90 度リブと同様に上昇している。

図7にリブ取り付け開始位置から $8 D$ 下流 (End wall から $3 D$ 上流) の曲がり部の影響を受けていない領域で の, リブ軸を通る断面内での平均速度ベクトル（90 度 リブのベクトル長さは, 60 度リブの 2 倍の長さとした) を, 図 8 に曲がり部内の主流に直交する 3 断面内の平 均速度ベクトル分布を示す. 図 7(a)の 90 度リブでは, リブを乗り越える流れによって, $y / D=0$ 一向かう二次流 れが生じる. 図7(b)の60 度少ブでは，図 5(b)で示した ように傾斜リブに沿う流れによって, $y / D=0$ では Outer wall から Inner wall 一向から流れとなる一対の渦を形成 する. 断面内速度の大きさを比較すると，90 度リブよ り 60 度リブの方が強い二次流れを生じさせることがわ かる. 図 8(a)の 90 度リブの曲がり部内流れは, 平滑管 (12) と同様で, 断面(I)では全域で Outer wall から Inner wall へ向から流れが生じ，断面(II)では曲がり部における流 体に㗢く遠心力によって生じる二次流れの渦が形成さ れ, 断面(III)で Inner wall 寄りに剥離領域, Outer wall 寄 りに曲がりによる渦が確認される. 図 8(b)の 60 度リブ 
の曲がり部内では, 断面(I)での $y / D=0$ の位置の二次流 れの向きは, 図 7(b)で示した方向と同じ Outer wall から Inner wall へ向から流れとなるため, リブ敷設面近くで は，リブと曲がりによる二次流れの向きが逆となるた め相殺され，90 度リブの場合に比べ二次流れは弱い. 断面(II)では曲がり部で流体に働く遠心力作用によって 生じる渦に加えて，傾斜リブの二次流れが影響し， 2 つの渦が形成されている.この流れはLESによる解析 (6)でも再現されている. 断面(III)では, Inner wall 寄りに 剥離領域, Outer wall 寄り 2 つ渦が確認される. 傾斜 リブの場合, リブによる二次流れと曲がり部で生じる 二次流れとの干渉によって, 曲がり部内は複雑な平均 速度ベクトル分布となることがわかる. 本論文で扱っ た傾斜リブの配置は, 高い熱伝達と同時に, 高い㽵力 損失を生じることが報告(2)(6)されており, 他のリブ配置 に比べ圧力損失が増加する原因は，これらリブと急激 曲がりによる二次流れの干渉によるものと考えられる.

\section{4. 結}

180 度急激曲がり部を有する, 90 度および 60 度りブ付 き往復流路内の, 粒子画像流速計による二次元乱流計測を 行い, 以下の結論を得た.

(1) 60 度リブは, 直線流路部においてリブ間の流れの剥 離・再付着と, 傾斜リブに沿う流れによる強い二次 流れを生じさせ, リブ間の乱れ強度およびレイノル ズ応力を上昇させる.

(2) 曲がり部内およびその直後では, 曲がりによる遠心 力で生じる二次流れと, 60 度リブにより生じる二次 流れの干渉で複雑な流れとなり, 乱れ強度は局所的 に上昇する.

\section{文献}

(1) Mochizuki, S., et al., Detailed measurements of local heat transfer coefficients of turbulent flow in smooth and rib-roughened serpentine passages with a 180 sharp bend, Transaction of the Japan Society of Mechanical Engineers, Series B, Vol. 64, No.623(1998), pp.2216-2223.

(2) Mochizuki, S., et al., Effect of rib arrangements on pressure drop and heat transfer in a rib-roughened channel with a sharp $180 \mathrm{deg}$ turn, Transactions of the ASME, Journal of Turbomachinery, Vol.119 (1997), pp.610-616.

(3) Mochizuki, S., et al., Detailed measurements of local heat transfer coefficients in turbulent flow through smooth and rib-roughened serpentine passages with a $180^{\circ}$ sharp bend, International Journal of Heat and Mass Transfer, Vol. 42 (1999), pp.1925-1934.

(4) Zhang, Y.M., et al., Surface heating effect on local heat transfer in a rotating two-pass square channel with 60 deg angled rib turbulators, Transactions of the ASME, Journal of Turbomachinery, Vol.117
(1995), pp.272-279.

(5) Murata, A., Mochizuki, S., Aiding and opposing contributions of centrifugal buoyancy on turbulent heat transfer in a two-pass transverse- or angled-rib-roughened channel with sharp 180 turns, International Journal of Heat and Mass Transfer, vol. 47 (2004) pp.3721-3743.

(6) Murata, A., Mochizuki, S., Effect of rib orientation and channel rotation on turbulent heat transfer in a two-pass square channel with sharp $180^{\circ}$ turns investigated by using large eddy simulation, International Journal of Heat and Mass Transfer, Vol. 47 (2004), pp.2599-2618.

(7) Rau, G., et al., The effect of periodic ribs on the local aerodynamic and heat transfer performance of a straight cooling channel, Transactions of the ASME, Journal of Turbomachinery, Vol.120 (1998), pp.368-375.

(8) Liou, T.M., et al., Fluid flow and heat transfer in a rotating two-pass square duct with in-line 90-deg ribs, Transactions of the ASME, Journal of Turbomachinery, Vol.124 (2002), pp.260-268.

(9) J. Schabacker., et al., PIV investigation of the flow characteristics in an internal coolant passage with $45 \mathrm{deg}$ rib arrangement, ASME Paper, 99-GT-120.

(10) Son, S.Y., et al., PIV flow measurements for heat transfer characterization in two-pass square channels with smooth and 90deg ribbed walls, International Journal of Heat and Mass Transfer, Vol.45 (2002), pp.4809-4822.

(11) Chanteloup, D., Boelcs, A., Flow effects on the bend region heat transfer distribution of 2-pass internal coolant passages of gas turbine airfoils, Proceedings of ASME Turbo Expo 2003, GT2003-38702.

(12) Saito, H., et al., Two-dimensional velocity measurement of turbulent flow in smooth and rib-roughened square two-pass channels by using particle image velocimetry, Transaction of the Japan Society of Mechanical Engineer, Vol. 73, No.730(2007), pp.1393-1398.

(13) Beak, S. J., Lee, S. J., A new two-frame particle tracking algorithm using match probability, Experiments in Fluids, Vol.22 (1996), pp.23-32.

(14) Huang, H.T., Fiedler, H.E., Reducing time interval between successive exposures in video PIV, Experiments in Fluids, Vol.17 (1994), pp.356-363.

(15) ANSI/ASME PTC 19.1, Measurement Uncertainty, (1985), ASME. 